\title{
Analisis Morfometrik Lebah Madu Pekerja Apis cerana Budidaya pada Dua Ketinggian Tempat yang Berbeda
}

\author{
Morphometrics Analyses of Apis cerana Workers Cultivated at Different Altitude \\ Novita, Rustama Saepudin, Sutriyono \\ Jurusan Peternakan, Fakultas Pertanian, Universitas Bengkulu \\ Jalan W.R. Supratman Kandang Limun Bengkulu 38371A
}

\begin{abstract}
S
This research aimed to compare the morphometric of worker bees Apis cerana lives at different altitudes which were high altitude $(500-<1000 \mathrm{~m}$ above sea level) and low altitude (0-100 $\mathrm{m}$ above sea level). The experimental animals were 50 Apis cerana collected from each altitudes. A projector microscope (LAS EZ V2.0.0) of 8x magnification was used in body measurement which was conducted in Animal Laboratory University of Bengkulu. Results showed that body weight, length of proboscis, femur length of worker bees of high and low altitude (introduced and local bees) are significantly different $(\mathrm{P}<0.05)$. However, the length of tibia, hind metatarsus, width of wings and and the forth abdominal tergit $(\mathrm{P}>0.05)$. The highest body weight and hind femur length werel observed in high and low altitudes. Infact, prosbocis length was the highest in low level altitude habitat. In contrasly, the measurement of length of hind femur was the highest in high altitude (kepahiyang) and the the longest proboscis was found in low altitude (Bengkulu city). The results indicate that the differences were due to the adaptation processes to the environment. It can be concluded that the altitude of habitat plays an important role to the morphometric of workers group of Apis cerana.

Keywords: Apis cerana, morphometric, the altitude
\end{abstract}

\begin{abstract}
ABSTRAK
Penelitian ini bertujuan untuk membandingkan morfometrik lebah madu pekerja Apis cerana berdasarkan perbedaan tempat hidup pada dataran tinggi $(500-<1000 \mathrm{~m} \mathrm{dpl})$ dan dataran rendah (0-100 m dpl). Penelitian ini menggunakan sampel 50 ekor lebah Apis cerana di setiap lokasi. Pengukuran bagian tubuh lebah madu dilakukan di Laboratorium Peternakan Universitas Bengkulu dengan menggunakan mikroskop projektor (LAS EZ V2.0.0) perbesaran 8 kali. Hasil penelitian menunjukkan bahwa berat badan (BB), panjang probosis (PP) dan panjang femur tungkai belakang (PFB) lebah madu pekerja di dataran tinggi dan dataran rendah (lebah introduksi dan lebah alami) berbeda nyata $(\mathrm{P}<0,05)$, sedangkan panjang tibia, metatarsus tungkai belakang, panjang sayap, lebar sayap dan ukuran tergit ke- 4 abdomen secara statistik tidak ada perbedaan $(\mathrm{P}>0,05)$. Berat badan dan panjang femur tungkai belakang tertinggi diperoleh pada lebah madu dataran tinggi
\end{abstract}


(Kepahiang), sedangkan panjang probosis tertinggi diperoleh pada lebah madu alami di dataran rendah (Kota Bengkulu). Ada indikasi bahwa perbedaan ini terjadi dalam upaya proses adaptasi lebah terhadap lingkungan hidupnya. Dari temuan di atas dapat disimpulkan bahwa ketinggian tempat hidup berpengaruh terhadap morfometrik lebah madu pekerja Apis cerana.

Kata Kunci : Apis cerana, morfometrik, ketinggian tempat

\section{PENDAHULUAN}

Indonesia termasuk negara beriklim tropis dan memiliki keanekaragaman jenis flora dan fauna. Salah satu keanekaragaman fauna yang dimiliki adalah lebah madu. Beberapa macam spesies lebah madu yang terdapat di Indonesia, yaitu Apis cerana, A. mellifera, A. koschevnikovi (Tingek et al., 1988), A. dorsata (Ruttner, 1988), A. nigrocincta (Hadisoesilo et al., 1995), dan A. andreniformis (Wu dan Kuang., 1987).

Masyarakat pedesaan lebih memilih untuk membudidayakan lebah madu $A$. cerana setelah $A$. mellifera, hal ini karena $A$. cerana mempunyai daya adaptasi tinggi terhadap iklim tropis, tahan terhadap tungau parasit, agresif dan mudah diternakkan dengan cara yang sederhana (Morse, 1967). Sedangkan A. mellifera yang rentan terhadap serangan tungau parasit dan tidak agresif (Gojmerac, 1983). Lebah $A$. cerana termasuk serangga sosial yang hidup dalam satu koloni. Satu koloni lebah madu terdiri dari satu lebah ratu (queen), ratusan lebah jantan (drone), dan ribuan lebah pekerja (worker). Setiap anggota koloni memiliki spesialisasi tugas dalam tingkatan sosial lebah madu. Untuk lebah madu ratu dan lebah madu jantan merupakan anggota koloni yang melakukan aktivitas reproduksi. Sedangkan lebah madu pekerja melakukan aktivitas dalam pemenuhan kebutuhan koloni seperti mencari pakan, membuat sarang bahkan mempertahankan koloni.

Potensi pengembangan atau pendayagunaan suatu spesies lebah didasari oleh keragaman genetik. Keragaman yang tinggi akan menguntungkan karena berpeluang untuk lebih mudah beradaptasi pada perubahan lingkungan, sehingga mampu bertahan hidup. Keragaman itu dapat termanifestasi pada ciri-ciri morfologi, morfologi lebah sangat penting untuk menentukan pertumbuhan spesies lebah sehubungan dengan pengumpulan polen, karena polen bernutrisi tinggi sangat penting bagi pertumbuhan larva dan perkembangan fisiologis lebah pekerja (Keller et al., 2005). Dengan melihat morfometrik dapat memprediksi produksi dari lebah madu, karena faktor utama banyaknya nektar yang dikumpulkan oleh lebah madu adalah kapasitas 
kantung madu (Erwan, 2003). Lebih lanjut Erwan (2003) menyatakan bahwa kapasitas kantung madu tergantung dari ukuran tubuh dari lebah pekerja.

Indonesia termasuk wilayah yang beriklim tropis, sehingga sangat ideal untuk mengembangbiakkan dan membudidayakan lebah madu, karena rata-rata suhu udaranya 26$35^{\circ} \mathrm{C}$. Lebah madu $A$. cerana dapat dipelihara baik di dataran tinggi, maupun dataran rendah. Menurut Murtidjo (1991), pada temperatur $20^{\circ} \mathrm{C}$ lebah madu mulai aktif dalam usahanya memperoleh nektar dan polen, namun waktu yang dibutuhkan dalam memperoleh nektar dan polen relatif pendek, sedangkan pada temperatur sekitar $30^{\circ} \mathrm{C}$ lebah sangat aktif mencari nektar atau polen namun waktu yang dibutuhkan untuk mengumpulkannya relatif lama. Sehingga dengan adanya perubahan temperatur akan terjadi adaptasi morfologi (bentuk fisik) yang merupakan penyesuaian bentuk tubuh makhluk hidup terhadap lingkungannya. Namun sampai saat ini belum ada informasi mengenai perbedaan morfometrik dari lebah madu yang ada di dataran tinggi (Kepahiang) pada ketinggian 500$<1000 \mathrm{~m} \mathrm{dpl}$, dan di dataran rendah (Kota Bengkulu) pada ketinggian 0$100 \mathrm{~m}$ dpl. Pengukuran morfometrik pada bagian-bagian tubuh lebah madu untuk mengetahui ada tidaknya perbedaan morfometrik lebah madu pada dua ketinggian tempat yang berbeda.

Tilde et al. (2000) dalam penelitian $A$. cerana di Filipina dengan menggunakan 101 sampel, menganalisis 39 karakteristik lebah madu A. cerana, hasilnya menunjukkan bahwa lebah $A$. cerana dari daerah Palawan berbeda dengan yang ada di daerah bagian Filipina lainnya yaitu memiliki ukuran sayap dan kaki lebih panjang. Mattu dan Verma (1984a dan 1984b) yang telah meneliti morfologi lebah $A$. cerana di daerah Kashmir (India Utara) pada dua ketinggian tempat berbeda, yaitu 600-1700 m dpl dan 2000-3000 m dpl, menunjukkan bahwa ukuran tungkai belakang, sayap depan, beberapa tergit dan sternit abdomen lebah di lokasi 600-1700 m dpl lebih kecil daripada bagian-bagian tubuh yang sama pada lebah di lokasi 2000-3000 $\mathrm{m}$ dpl. Berdasarkan hasil penelitian tersebut perlu dilakukan penelitian lebah madu pada tempat yang berbeda.

Penelitian morfometrik lebah madu pekerja $A$. cerana budidaya pada dua ketinggian tempat yang berbeda (dataran tinggi $500-<1000 \mathrm{~m}$ dpl dan dataran rendah 0-100 $\mathrm{m} \mathrm{dpl)}$ sangat perlu dilaksanakan.

Penelitian ini bertujuan untuk membandingkan morfometrik lebah madu pekerja Apis cerana berdasarkan perbedaan tempat hidup pada dataran tinggi $(500-<1000 \mathrm{~m}$ 
dpl) dan dataran rendah $(0-100 \mathrm{~m}$ dpl).

\section{MATERI DAN METODE}

Penelitian ini dilaksanakan pada bulan April 2013, pengambilan sampel lebah madu pekerja Apis cerana dilakukan di daerah Kepahiang dan di daerah Bengkulu, kemudian dilakukan pengukuran di Laboratorium Peternakan Fakultas Pertanian Universitas Bengkulu.

Peralatan dan bahan yang digunakan dalam penelitian ini antara lain timbangan analitik (kapasitas 210 gram dengan ketelitian 0,0001 gram), miskropkop projektor(LAS EZ V2.0.0, made in Switzerland), penggaris besi, pinset, botol kecil, perlengkapan keamanan dari serangan lebah, alkohol $70 \%$, lebah madu pekerja dan lain-lain yang dianggap perlu.

\section{Prosedur}

\section{Pengambilan Sampel}

Penelitian ini menggunakan lebah madu $A$. cerana yang diambil pada pagi hari (pukul 09:00 wib) dari dataran tinggi (Kepahiang) pada ketinggian $500-<1000 \mathrm{~m}$ dpl, dan dataran rendah (Kota Bengkulu) pada ketinggian 0-100 m dpl. Adapun caranya adalah pertama-tama mengambil lebah madu dengan cara memasang kantong plastik bening pada gerbang sarang sehingga lebah pekerja yang akan terbang keluar sarang terjebak dalam kantong dari koloni yang berbeda yang ada di dataran tinggi dan di dataran rendah. Ditiap lokasi dikoleksi masingmasing sebanyak 50 ekor lebah pekerja, kemudian dimasukkan ke dalam botol. Lebah dimatikan dengan alkohol $70 \%$ dan disimpan untuk pengerjaan lebih lanjut.

\section{Penimbangan dan Pengukuran} Penimbangan sampel dilakukan di Laboratorium. Peternakan Fakultas Pertanian Universitas Bengkulu, 10 ekor lebah dari masing-masing koloni ditimbang untuk mendapatkan bobot rata-rata lebah. Sehingga ada masing-masing lima bobot rata-rata lebah dari daerah dataran tinggi dan daerah dataran rendah. Sedangkan pengukuran morfometrik dilakukan dengan cara mematikan lebah dengan menggunakan alkohol $70 \%$ dan bagian-bagian tubuh yang akan diukur ditempatkan pada kaca objek yang ada di mikroskop projektor (LAS EZ V2.0.0, made in Switzerland). Pengukuran dilakukan menggunakan mikroskop projektor dengan perbesaran 8 kali.

Pengukuran dilakukan terhadap bagian-bagian tubuh lebah, yaitu panjang probosis (PP), panjang femur tungkai belakang (PFB), panjang tibia tungkai belakang (PTB), panjang metatarsus tungkai belakang 
(PMB), panjang sayap depan (PSD), lebar sayap depan (LSD), dan ukuran longitudinal tergit ke-4 abdomen (T4L). Sebagai data pendukung akan diamati lingkungan sekitar tempat budidaya lebah madu pekerja $A$. cerana.

3. Data yang diperoleh dianalisis anova menggunakan sofware SPSS for windows ver. 16.0, jika terdapat perbedaan yang nyata maka diuji lebih lanjut dengan DMRT (Steel dan Torrie, 1993).

\section{HASIL DAN PEMBAHASAN}

\section{Kondisi Klimat Lokasi Penelitian}

Gambaran umum mengenai kondisi Propinsi Bengkulu. Wilayah Bengkulu berbentuk memanjang sejajar dengan pantai Samudera Indonesia dan terletak diantara Lintang Selatan $2^{\circ}-5^{\circ}$ dan Bujur Timur $101^{\circ}-104^{\circ}$, dengan luas wilayah $20.000 \mathrm{~km}^{2}$. Iklim di Propinsi Bengkulu ditandai dengan jumlah rata-rata curah hujan di Provinsi Bengkulu adalah antara 3.000-4.000 $\mathrm{mm} / \mathrm{tahun}$ dan jumlah hari hujan rata-rata 130-200 hari/tahun, dengan bulan basah sepanjang tahun. Suhu udara/bulan rata-rata $26,3^{\circ} \mathrm{C}$ dengan suhu udara maksimum $32,3^{\circ} \mathrm{C}$ dan suhu udara minimum $21,9^{\circ} \mathrm{C}$. Kelembaban udara rata-rata $84,1 \%$. Sedangkan daerah dataran tinggi Kepahiang terletak pada ketinggian 500-1000 m dpl, dengan suhu udara rata-rata $24,0^{\circ} \mathrm{C}$ (maksimum sebesar $29,9^{\circ} \mathrm{C}$ dan sebesar $19,9^{\circ} \mathrm{C}$ ), kelembaban nisbi rata-rata bulanan $>$ 80\% (Anonimus, 2013).

\section{Berat Badan Lebah Madu Pekerja}

Hasil analisis ragam menunjukkan bahwa perbedaan ketinggian tempat berbeda nyata $(\mathrm{P}<0,05)$ terhadap berat badan lebah madu pekerja $A$. cerana. Berat badan tertinggi diperoleh pada daerah dataran tinggi (Kepahiang) yaitu $0,072 \pm 0.0089$ gram dan ukuran berat badan terendah terdapat pada lebah madu alami di dataran rendah (Kota Bengkulu) yang berkisar 0,055 \pm 0,0119 gram. Hal ini terjadi karena $A$. cerana dataran tinggi yang berukuran lebih besar daripada lebah dataran rendah sesuai dengan Bergmann's rule (Begon et al., 1986), yang menyatakan bahwa hewan endotermik berukuran lebih besar di daerah bersuhu lebih dingin dibandingkan hewan endotermik di daerah panas. Secara morfologis, ukuran tubuh $A$. cerana adalah yang paling kecil di antara keempat species lebah madu yang membentuk sarang di tempat tertutup. Namun demikian diantara $A$. cerana sendiri ukuran tubuhnya juga berbeda dari satu lokasi ke lokasi yang lain (Hadisoesilo, 2001). Berdasarkan data yang diperoleh daerah dataran tinggi Kepahiang terletak pada ketinggian 500-1000 m dpl, dengan suhu udara 
rata-rata $24,0^{\circ} \mathrm{C}$, dengan suhu udara maksimum sebesar $29,9^{\circ} \mathrm{C}$ dan suhu udara minimum sebesar $19,9^{\circ} \mathrm{C}$, kelembaban nisbi rata-rata bulanan $>$
$80 \%$.Tabel 1. Rataan hasil berat badan lebah madu pekerja A.cerana di lokasi yang berbeda

\begin{tabular}{cccc}
\hline \multirow{2}{*}{ Koloni } & \multicolumn{3}{c}{ Rataan Berat Badan Lebah Madu (gram) } \\
\cline { 2 - 4 } & $\begin{array}{c}\text { Kepahiang } \\
\text { (Budidaya) }\end{array}$ & $\begin{array}{c}\text { Kota Bengkulu } \\
\text { (Budidaya) }\end{array}$ & $\begin{array}{c}\text { Kota Bengkulu } \\
\text { (Alami) }\end{array}$ \\
\hline 1 & $0,071 \pm 0,0089$ & $0,067 \pm 0,0097$ & $0,057 \pm 0,0153$ \\
2 & $0,076 \pm 0,0094$ & $0,067 \pm 0,0102$ & $0,049 \pm 0,0046$ \\
3 & $0,072 \pm 0,0075$ & $0,075 \pm 0,0090$ & $0,056 \pm 0,0147$ \\
4 & $0,070 \pm 0,0091$ & $0,069 \pm 0,0134$ & $0,057 \pm 0,0118$ \\
5 & $0,070 \pm 0,0096$ & $0,070 \pm 0,0156$ & $0,056 \pm 0,0107$
\end{tabular}

Rataa

$\mathrm{n}$

$0,072 \pm 0,0089$ a

$0,069 \pm 0,0118^{b}$

$0,055 \pm 0,0119^{b}$

Keterangan : Superskrip yang berbeda pada baris yang sama menunjukkan berbeda nyata $(\mathrm{P}<0,05)$.

\begin{tabular}{lrrrr}
\multicolumn{2}{c}{ Menurut Ruttner } & $(1988)$ & mencari makanan. Makin besar tubuh \\
adaptasi terhadap & kondisi & $\begin{array}{l}\text { lebah maka makin jauh jarak } \\
\text { lingkungan }\end{array}$ mencerminkan & $\begin{array}{l}\text { terbangnya. Seperti Trigona spp } \\
\text { perubahan ukuran lebah pekerja. }\end{array}$ & $\begin{array}{l}\text { dengan ukuran } 5 \mathrm{~cm} \text { mempunyai } \\
\text { Roubik dan Ackerman (1987) }\end{array}$ \\
menambahkan bahwa untuk lebah & al., 2000).
\end{tabular}
sosial ukuran tubuh pekerja umumnya telah dianggap sebagai adaptasi untuk aktivitas mencari makan dan mengeksploitasi sumber daya bunga. Ukuran tubuh sangat mempengaruhi jarak terbang lebah

\section{Panjang Probosis (PP)}

Rataan hasil pengukuran panjang probosis pada ketinggian tempat yang berbeda disajikan pada Tabel 2. di bawah ini:

Tabel 2. Rataan hasil pengukuran Panjang Probosis lebah madu pekerja A. cerana di lokasi yang berbeda

Koloni Rataan Panjang Probosis (milimeter)




\begin{tabular}{cccc}
\hline & $\begin{array}{c}\text { Kepahiang } \\
(\text { Budidaya })\end{array}$ & $\begin{array}{c}\text { Kota Bengkulu } \\
\text { (Budidaya) }\end{array}$ & $\begin{array}{c}\text { Kota Bengkulu } \\
(\text { Alami) }\end{array}$ \\
\hline 1 & $2,652 \pm 0,3525$ & $2,775 \pm 0,2267$ & $2,891 \pm 0,2060$ \\
2 & $2,651 \pm 0,3137$ & $2,694 \pm 0,2972$ & $2,924 \pm 0,1285$ \\
3 & $2,532 \pm 0,4086$ & $2,773 \pm 0,2492$ & $2,907 \pm 0,1169$ \\
4 & $2,641 \pm 0,4018$ & $2,905 \pm 0,0685$ & $2,574 \pm 0,3649$ \\
5 & $2,455 \pm 0,3942$ & $2,671 \pm 0,3562$ & $2,793 \pm 0,3038$ \\
\hline Rataan & $2,586 \pm 0,3691^{\mathrm{b}}$ & $2,764 \pm 0,2609^{\text {a }}$ & $2,818 \pm 0,2684^{\text {a }}$ \\
\hline
\end{tabular}

Keterangan : Superskrip yang berbeda pada baris yang sama menunjukkan berbeda nyata $(\mathrm{P}<0,05)$.

Analisis ragam menunjukkan bahwa panjang probosis dipengaruhi oleh ketinggian tempat $(\mathrm{P}<0,05)$. Pada Tabel 2. ditunjukkan bahwa rata-rata panjang probosis $A$. cerana tertinggi ditemukan pada lebah madu $A$. cerana yang hidup secara alami di dataran rendah (Kota Bengkulu) yang tidak berbeda nyata $(\mathrm{P}>0,05)$ jika dibandingkan dengan $A$. cerana budidaya di dataran rendah (Kota Bengkulu). Jika dibandingkan dengan A. cerana di dataran tinggi maka panjang probosis $A$. cerana di dataran rendah lebih panjang $(\mathrm{P}<0,05)$ dari pada A. cerana di dataran tinggi (Kepahiang). Hal lain yang terbukti dari penelitian ini adalah bahwa ukuran panjang probosis $A$. cerana menjadi lebih panjang dengan perbedaan ketinggian tempat, perbedaan yang signifikan ini jelas terlihat pada lebah $A$. cerana yang telah lama hidup di dataran rendah Kota Bengkulu, di bandingkan dengan lebah madu yang dibudidayakan di dataran rendah Kota Bengkulu dan dataran tinggi
Kepahiang, dengan kisaran tertinggi $2,818 \pm 0,2684 \mathrm{~mm}$ dan terendah 2,586 $\pm 0,3691 \mathrm{~mm}$.

Hal itu ditunjukkan juga dari uji statistik, yaitu ukuran tersebut berbeda nyata antara lebah alami dari dataran rendah (Kota Bengkulu) dan lebah dari dataran tinggi (Kepahiang). Namun hasil sebaliknya terjadi pada lebah sesama daratan rendah (Kota Bengkulu) yaitu tidak adanya perbedaan nyata panjang probosis lebah madu budidaya dan alami. Mattu dan Venna (1983) menyatakan bahwa panjang probosis tidak berkorelasi dengan ketinggian tempat, tetapi lebih dipengaruhi oleh faktor morfologi bunga. Probosis yang berukuran panjang lebih sesuai untuk bunga-bunga dengan kedudukan nektar yang dalam, sedang probosis ukuran pendek untuk bunga-bunga dengan kedudukan nektar yang dangkal. Hal ini juga mengindikasikan bahwa ukuran probosis di dalam satu koloni lebah merupakan strategi populasi itu untuk memperluas peluang 
mendapatkan nektar yang cukup dari berbagai bunga dengan kedudukan nektar beragam.

Dalam penelitian ini ada perbedaan vegetasi antara dataran tinggi (Kepahiang) dan dataran rendah (Kota Bengkulu). Di Kepahiang vegetasi di sekitar sarang didominasi oleh tanaman kopi, hal ini sesuai dengan Saepudin et al. (2011) menyatakan bahwa produksi lebah madu jauh lebih tinggi di daerah perkebunan kopi karena ketersediaan pakan yang melimpah dan jumlah populasi lebah madu yang tinggi. Sedangkan di Kota
Bengkulu vegetasi di sekitar sarang beraneka ragam seperti sengon, kayu manis, mahoni dan lain-lain. Dengan adanya perbedaan vegetasi tersebut ada perbedaan jenis bunga yang ada disekitar sarang, perbedaan bungabunga tersebut akan menyebabkan perbedaan kedalaman nektar yang dapat berpengaruh terhadap panjang probosis.

\section{Panjang Femur Tungkai Belakang} (PFB)

Perbedaan ketinggian tempat terhadap rataan pajang femur tungkai belakang lebah madu pekerja A. cerana tertera pada Tabel 3.

Tabel 3. Rataan panjang femur tungkai belakang lebah madu pekerja A. cerana di lokasi yang berbeda

\begin{tabular}{cccc}
\hline \multirow{2}{*}{ Koloni } & \multicolumn{2}{c}{ Rataan Panjang Femur Tungkai Belakang (milimeter) } \\
\cline { 2 - 4 } & $\begin{array}{c}\text { Kepahiang } \\
\text { (Budidaya) }\end{array}$ & $\begin{array}{c}\text { Kota Bengkulu } \\
\text { (Budidaya) }\end{array}$ & $\begin{array}{c}\text { Kota Bengkulu } \\
\text { (Alami) }\end{array}$ \\
\hline 1 & $2,026 \pm 0,2802$ & $2,009 \pm 0,1353$ & $1,981 \pm 0,1774$ \\
2 & $2,039 \pm 0,1476$ & $2,096 \pm 0,0742$ & $2,059 \pm 0,1623$ \\
3 & $2,198 \pm 0,0689$ & $2,073 \pm 0,1019$ & $2,174 \pm 0,1453$ \\
4 & $2,118 \pm 0,0578$ & $2,140 \pm 0,1679$ & $1,977 \pm 0,1529$ \\
5 & $2,119 \pm 0,1460$ & $2,039 \pm 0,0769$ & $1,873 \pm 0,1346$ \\
\hline Rataan & $2,100 \pm 0,1667$ a & $2,071 \pm 0,1210^{\mathrm{ab}}$ & $2,013 \pm 0,1897^{\mathrm{b}}$ \\
\hline
\end{tabular}

Keterangan : Superskrip yang berbeda pada baris yang sama menunjukkan berbeda nyata $(\mathrm{P}<0,05)$.

Hasil analisis ragam menunjukkan bahwa panjang femur dipengaruhi oleh ketinggian tempat berbeda nyata $(\mathrm{P}<0,05)$ antara lebah madu dataran tinggi (Kepahiang) dan dataran rendah (Kota Bengkulu) yang tertinggi sebesar 2,100 $\pm 0,1667 \mathrm{~mm}$ dan terendah 2,013 $\pm 0,1897 \mathrm{~mm}$. Femur merupakan bagian kaki lebah yang digunakan sebagai tumpuan pada saat terbang, sehingga besar dan kecilnya femur yang dipengaruhi oleh banyaknya aktifitas terbang lebah. 
Data pada Tabel 3. ditunjukkan bahwa ukuran panjang femur lebah madu di dataran tinggi Kepahiang lebih panjang di bandingkan dengan dataran rendah Kota Bengkulu. Hal ini dipengaruhi antara lain oleh keadaan lingkungan yang berbeda, Michener (1974), menyatakan bahwa faktor lingkungan yang mempengaruhi aktivitas terbang dan mencari polen adalah suhu, angin, curah hujan, kelembaban dan intensitas cahaya. Dalam penelitian ada perbedaan kondisi lingkungan sehingga diperkirakan akan mempengaruhi aktivitas terbang dan mencari makan yang selanjutnya akan berpengaruh pada perkembangan femur tungkai belakang. Ada perbedaan suhu, kelembaban dan curah hujan antara dataran tinggi (Kepahiang) dan dataran rendah (Kota Bengkulu) yaitu Kota Bengkulu suhu udara/bulan rata-rata $26,3^{\circ} \mathrm{C}$ dengan suhu udara maksimum $32,3^{\circ} \mathrm{C}$ dan suhu udara minimum $21,9^{\circ} \mathrm{C}$. Kelembaban udara rata-rata $84,1 \%$. Sedangkan daerah dataran tinggi Kepahiang terletak pada ketinggian 500-1000m dpl, dengan suhu udara rata-rata $24,0^{\circ} \mathrm{C}$ (maksimum sebesar $29,9^{\circ} \mathrm{C}$ dan sebesar $19,9^{\circ} \mathrm{C}$ ), kelembaban nisbi rata-rata bulanan $>$ 80\% (Anonimus, 2013).

\section{Panjang Tibia dan Panjang Metatarsus Tungkai Belakang (PTB dan PMB)}

Pada Tabel 4 dan Tabel 5 . ditunjukkan bahwa panjang tibia tungkai belakang lebah madu pekerja tidak menunjukkan perbedaan yang nyata $(P>0,05)$, hal serupa dari hasil panjang metatarsus tungkai belakang yang juga penunjukkan hasil yang tidak berbeda antara dataran tinggi Kepahiang dan dataran rendah Kota Bengkulu (budidaya maupun alami), dengan kisaran tertinggi panjang tibia tungkai belakang yaitu 2,524 \pm 0,0952 $\mathrm{mm}$ dan panjang metatarsus tungkai belakang tertinggi 2,022 \pm 0,0693 mm.

Hewan mempunyai kemampuan adaptasi terhadap perubahan suhu lingkungan seperti halnya lebah madu. Perubahan morfologi untuk tibia tungkai belakang dan metatarsus tungkai belakang jika dikaitkan dengan aktifitas harian untuk mencari makan dan aktifitas lain organ tersebut bukan merupakan tumpuan utama, tetapi di pengaruhi oleh faktor lingkungan yaitu suhu udara. Hal ini sesuai dengan Corbet et al. (1993) yang menyatakan bahwa suhu udara (temperatur) merupakan faktor lingkungan yang berpengaruh penting terhadap aktifitas lebah madu. Suhu udara, kelembaban dan intensitas cahaya berhubungan erat dengan ketersediaan pakan (Hilario et al., 2000). 
Tabel 4. Rataan panjang tibia tungkai belakang lebah madu pekerja A. cerana berdasarkan dua ketinggian tempat yang berbeda.

\begin{tabular}{cccc}
\hline \multirow{2}{*}{ Koloni } & \multicolumn{2}{c}{ Rataan Panjang Tibia Tungkai Belakang (milimeter) } \\
\cline { 2 - 4 } & $\begin{array}{l}\text { Kepahiang } \\
\text { (Budidaya) }\end{array}$ & $\begin{array}{c}\text { Kota Bengkulu } \\
\text { (Budidaya) }\end{array}$ & $\begin{array}{c}\text { Kota Bengkulu } \\
\text { (Alami) }\end{array}$ \\
\hline 1 & $2,514 \pm 0,0873$ & $2,462 \pm 0,0874$ & $2,502 \pm 0,0935$ \\
2 & $2,466 \pm 0,1013$ & $2,549 \pm 0,1096$ & $2,478 \pm 0,1036$ \\
3 & $2,504 \pm 0,0959$ & $2,514 \pm 0,1180$ & $2,538 \pm 0,1335$ \\
4 & $2,500 \pm 0,1344$ & $2,594 \pm 0,0671$ & $2,479 \pm 0,1097$ \\
5 & $2,539 \pm 0,0693$ & $2,503 \pm 0,0487$ & $2,416 \pm 0,1151$ \\
\hline Rataan & $2,505 \pm 0,0987^{\text {a }}$ & $2,524 \pm 0,0952^{\text {a }}$ & $2,483 \pm 0,1128^{\text {a }}$ \\
\hline
\end{tabular}

Keterangan : Superskrip yang berbeda pada baris yang sama menunjukkan tidak berbeda nyata $(\mathrm{P}>0,05)$.

\section{Panjang dan Lebar Sayap Depan (PSD dan LSD)}

Analisis ragam menunjukkan bahwa panjang dan lebar sayap depan berdasarkan perbedaan ketinggian tempat berpengaruh tidak nyata $(\mathrm{P}>0,05)$. Hasil penelitian menunjukkan bahwa ukuran panjang sayap depan berbeda tidak nyata $(P>0.05)$ antara dataran tinggi dan dataran rendah. Panjang sayap tertinggi diperoleh pada daerah dataran tinggi (Kepahiang) ukurannya sebesar 7,680 $\pm 0,1980 \mathrm{~mm}$ dan terendah pada lebah madu alami yang terdapat di dataran rendah (Kota Bengkulu) yang berkisar 7,513 $\pm 0,1646 \mathrm{~mm}$ (Tabel 6). Untuk hasil ukuran lebar sayap menunjukkan bahwa berbeda tidak nyata pada kedua tempat baik yang di daerah dataran tinggi (Kepahiang) maupun dataran rendah (Kota Bengkulu) yang besarnya 2,604 $\pm 0,1078 \mathrm{~mm}$ dan terendah 2,557 $\pm 0,1353 \mathrm{~mm}$. Hal ini dipengaruhi oleh faktor ada tidaknya sumber pakan di sekitar lokasi, yang pada umumnya lebah tidak terlalu jauh dari sarangnya mencari makanan. Seperti halnya A. cerana yang cenderung menghampiri jenis tanaman bunga yang terdekat dengan sarangnya. Kemungkinan lebah madu hanya menemukan pada satu lokasi karena lokasi tersebut dekat dengan sarang. Sesuai dengan hasil penelitian Kevanat al. (1995) jarak pencarian pakan A. cerana 100$500 \mathrm{~m}$ dari sarang. Faktor lainnya adalah lingkungan seperti ketinggian daerah, suhu kelembaban dan intensitas cahaya. Menurut Chasanah (2010) suhu udara dan intensitas cahaya berpengaruh positif terhadap jumlah individu serangga, sedangkan kelembaban berpengaruh negatif terhadap jumlah individu serangga 
Tabel 5. Rataan panjang metatarsus tungkai belakang lebah madu pekerja $A$. cerana berdasarkan dua ketinggian tempat yang berbeda

\begin{tabular}{cccc}
\hline \multirow{2}{*}{ Koloni } & \multicolumn{2}{c}{ Rataan Panjang Metatarsus Tungkai Belakang (milimeter) } \\
\cline { 2 - 4 } & $\begin{array}{c}\text { Kepahiang } \\
\text { (Budidaya) }\end{array}$ & $\begin{array}{c}\text { Kota Bengkulu } \\
\text { (Budidaya) }\end{array}$ & $\begin{array}{c}\text { Kota Bengkulu } \\
\text { (Alami) }\end{array}$ \\
\hline 1 & $1,954 \pm 0,1283$ & $2,017 \pm 0,1011$ & $2,025 \pm 0,1050$ \\
2 & $2,060 \pm 0,0678$ & $2,008 \pm 0,0451$ & $2,033 \pm 0,0642$ \\
3 & $2,057 \pm 0,0708$ & $2,060 \pm 0,0524$ & $2,043 \pm 0,0938$ \\
4 & $1,999 \pm 0,2194$ & $2,044 \pm 0,0483$ & $1,967 \pm 0,0408$ \\
5 & $2,024 \pm 0,0605$ & $1,980 \pm 0,0666$ & $1,979 \pm 0,1141$ \\
\hline Rataan & $2,019 \pm 0,1260^{\text {a }}$ & $2,022 \pm 0,0693^{\text {a }}$ & $2,009 \pm 0,0907^{\text {a }}$ \\
\hline
\end{tabular}

Keterangan : Superskrip yang berbeda pada baris yang sama menunjukkan tidak berbeda nyata $(\mathrm{P}>0,05)$

Menurut Guslim (2007)

semakin tinggi suatu tempat, semakin rendah suhu di tempat tersebut. Demikian juga intensitas matahari semakin berkurang. Suhu dan penyinaran inilah yang nantinya akan digunakan untuk menggolongkan tanaman apa yang sesuai untuk dataran tinggi atau dataran rendah. Ketinggian tempat dari permukaan laut juga sangat menentukan pembungaan tanaman. Tanaman berbuahan yang ditanam di dataran rendah berbunga lebih awal dibandingkan dengan yang ditanam pada dataran tinggi (Ashari, 2006).

Tabel 6. Rataan panjang sayap lebah madu pekerja A. cerana berdasarkan dua ketinggian tempat yang berbeda

\begin{tabular}{cccc}
\hline \multirow{3}{*}{ Koloni } & \multicolumn{3}{c}{ Rataan Panjang Sayap (milimeter) } \\
\cline { 2 - 4 } & $\begin{array}{c}\text { Kepahiang } \\
\text { (Budidaya) }\end{array}$ & $\begin{array}{c}\text { Kota Bengkulu } \\
\text { (Budidaya) }\end{array}$ & $\begin{array}{c}\text { Kota Bengkulu } \\
\text { (Alami) }\end{array}$ \\
\hline 1 & $7,881 \pm 0,2767$ & $7,549 \pm 0,1668$ & $7,523 \pm 0,1673$ \\
2 & $7,637 \pm 0,1227$ & $7,552 \pm 0,0990$ & $7,600 \pm 0,1941$ \\
3 & $7,656 \pm 0,1545$ & $7,628 \pm 0,0802$ & $7,598 \pm 0,1155$ \\
4 & $7,607 \pm 0,1005$ & $7,612 \pm 0,0871$ & $7,379 \pm 0,0782$ \\
5 & $7,618 \pm 0,1733$ & $7,504 \pm 0,1370$ & $7,465 \pm 0,1529$ \\
\hline Rataan & $7,680 \pm 0,1980^{\text {a }}$ & $7,569 \pm 0,1226^{\text {a }}$ & $7,513 \pm 0,1646^{\text {a }}$ \\
\hline
\end{tabular}

Keterangan : Superskrip yang berbeda pada baris yang sama menunjukkan tidak berbeda nyata $(P>0,05)$. 
Tabel 7. Rataan lebar sayap lebah madu lebah madu pekerja A. cerana berdasarkan dua ketinggian tempat yang berbeda

\begin{tabular}{cccc}
\hline \multirow{3}{*}{ Koloni } & \multicolumn{3}{c}{ Rataan Lebar Sayap (milimeter) } \\
\cline { 2 - 4 } & $\begin{array}{c}\text { Kepahiang } \\
\text { (Budidaya) }\end{array}$ & $\begin{array}{c}\text { Kota Bengkulu } \\
\text { (Budidaya) }\end{array}$ & $\begin{array}{c}\text { Kota Bengkulu } \\
\text { (Alami) }\end{array}$ \\
\hline 1 & $2,582 \pm 0,0919$ & $2,596 \pm 0,0763$ & $2,612 \pm 0,0915$ \\
2 & $2,669 \pm 0,1591$ & $2,530 \pm 0,1518$ & $2,520 \pm 0,0959$ \\
3 & $2,541 \pm 0,0709$ & $2,597 \pm 0,0954$ & $2,638 \pm 0,0925$ \\
4 & $2,599 \pm 0,0838$ & $2,508 \pm 0,1681$ & $2,491 \pm 0,1596$ \\
5 & $2,628 \pm 0,0775$ & $2,554 \pm 0,1626$ & $2,605 \pm 0,0670$ \\
\hline Rataan & $2,604 \pm 0,1078^{\text {a }}$ & $2,557 \pm 0,1353^{\text {a }}$ & $2,573 \pm 0,1143^{\text {a }}$ \\
\hline
\end{tabular}

Keterangan : Superskrip yang berbeda pada baris yang sama menunjukkan tidak berbeda nyata $(\mathrm{P}>0,05)$.

Panjang sayap juga dipengaruhi oleh ada tidaknya pakan yang terdapat sekitar sarang lebah madu. Di dataran tinggi (Kepahiang) terdapat sumber pakan yang didapat dari pohon kopi dan juga pohon teh yang merupakan tanaman penghasil polen, sehingga bunga kopi dan teh dapat dimanfaatkan dengan baik. Selain pohon kopi dan pohon teh terdapat juga pohon kaliandra disekitar sarang yang merupakan jenis tanaman pakan lebah yang sangat disukai karena nektar yang dimilikinya (Husaini, 1986). Tetapi, penyebaran tanaman kaliandra di lokasi penelitian tidak merata. Hal ini disebabkan kaliandra bukan tanaman yang dibudidayakan dan hanya ditanam untuk mengisi tempattempat kosong. Sedangkan di dataran rendah Kota Bengkulu sumber pakan yang didapat dari berbagai ragam tanaman yang hidup disekitar sarang lebah madu $A$. cerana.

\section{Ukuran Longitudinal Tergit Ke-4}

\section{Abdomen (T4L)}

Hasil penelitian menunjukkan bahwa ukuran longitudinal tergit ke4 abdomen berbeda tidak nyata $(\mathrm{P}>0,05)$ antara dataran tinggi (Kepahiang) dan dataran rendah (Kota Bengkulu). Hal ini dapat terjadi tergantung dengan lama waktu suatu lebah untuk dapat memenuhi kantong polen atau kantong nektar yang bervariasi, serta berapa banyak bunga yang harus dikunjungi juga bervariasi. Variasi waktu dan jumlah kunjungan lebah ditentukan oleh berbagai faktor, antara lain jarak dari sarang, banyaknya nektar atau polen pada bunga, dan melimpahnya 
bunga disuatu tempat (Gojmerac, 1983).

Pada Tabel 8. ditunjukkan bahwa ukuran longitudinal tergit ke4 abdomen tertinggi sebesar 3,704 \pm 0,1903 mm ditemukan di dataran tinggi (Kepahiang) dan terendah pada lebah madu A. cerana di dataran rendah (Kota Bengkulu). Hal tersebut terjadi dengan adanya adaptasi morfologi lebah madu terhadap kondisi lingkungan pada kedua tempat yang hampir sama, sehingga perkembangan ukuran longitudinal tergit ke-4 abdomen hampir sama. Pengaruh lain yaitu adanya faktor dari luar, seperti makanan sebagai salah satu kebutuhan utama perkembangan tubuh lebah. Hal ini sesuai dengan Gojmerac (1983), yang menyatakan sebagian besar kebutuhan protein koloni lebah madu diperoleh dari polen. Protein ini Tabel 8. Rataan ukuran longitudinal tergit ke-4 abdomen lebah madu pekerja $A$. cerana berdasarkan dua ketinggian tempat yang berbeda

\begin{tabular}{cccc}
\hline \multirow{2}{*}{ Koloni } & \multicolumn{2}{c}{ Rataan Ukuran Longitudinal Tergit ke-4 Abdomen (milimeter) } \\
\cline { 2 - 4 } & Kepahiang (Budidaya) & $\begin{array}{c}\text { Kota Bengkulu } \\
\text { (Budidaya) }\end{array}$ & $\begin{array}{c}\text { Kota Bengkulu } \\
\text { (Alami) }\end{array}$ \\
\hline 1 & $3,593 \pm 0,1836$ & $3,607 \pm 0,2486$ & $3,723 \pm 0,1126$ \\
2 & $3,683 \pm 0,1895$ & $3,675 \pm 0,1497$ & $3,586 \pm 0,1494$ \\
3 & $3,757 \pm 0,1695$ & $3,704 \pm 0,1533$ & $3,628 \pm 0,2263$ \\
4 & $3,709 \pm 0,2449$ & $3,730 \pm 0,1154$ & $3,587 \pm 0,1388$ \\
5 & $3,777 \pm 0,1483$ & $3,694 \pm 0,2238$ & $3,666 \pm 0,1228$ \\
\hline Rataan & $3,704 \pm 0,1903^{\text {a }}$ & $3,682 \pm 0,1807^{\text {a }}$ & $3,638 \pm 0,1577^{\text {a }}$ \\
\hline
\end{tabular}

Keterangan : Superskrip yang berbeda pada baris yang sama menunjukkan tidak berbeda sangat penting untuk pertumbuhan dan perkembangan tubuh lebah. Pada larva lebah, protein ini dapat memperbaiki jaringan tubuh dan menjalankan fungsi tubuh lainnya. Morse dan Hooper menyatakan bahwa, seperti hewan yang lain lebah madu juga membutuhkan vitamin dan mineral yang dihasilkan dari polen. Dalam penelitian ini kondisi lingkungan, khususnya sumber pakan cukup kecukupan pakan seperti protein, vitamin dan mineral hampir sama untuk kedua lokasi. Kesamaan kondisi lingkungan, khususnya sumber pakan yang tercukupi menghasilkan tingkat perkembangan ukuran longitudinal tergit ke-4 abdomen yang hampir sama. tersedia di sekitar sarang sehingga

\footnotetext{
nyata $(\mathrm{P}>0,05)$.
} 


\section{KESIMPULAN}

Dari hasil penelitian dapat disimpulkan bahwa ada perbedaan morfologi lebah di daerah dataran tinggi dan dataran rendah yang meliputi berat badan dan bagian tubuh yang terdiri dari panjang probosis (PP), dan panjang femur tungkai belakang (PFB). Berat badan dan panjang femur tertinggi diperoleh pada lebah madu di dataran tinggi (Kepahiang), sedangkan panjang probosis tertinggi diperoleh pada lebah madu alami di dataran rendah (Kota Bengkulu).

\section{SARAN}

Untuk mengetahui apakah perubahan morfometrik berpengaruh terhadap produksi madu maka, diperlukan penelitian lebih lanjut tentang hubungan antara morfometrik dengan produksi.

\section{DAFTAR PUSTAKA}

Amano, K., T. Nemoto., and T.A Heard. 2000. What are stingless bees and why and how to use them as crop pollinator? A review JARQ 34: 183-190.

Anonimus. 2013. Kondisi Geografis dan Administrasi Wilayah Kabupaten
Kepahiang.http://kepahiangka b.go.id/index.php/profildaerah/kondisi-geografis-danadministrasi-wilayah. 28 Mei 2013.

Ashari, S. 2006. Meningkatkan Keunggulan Berbuahan Tropis Indonesia, Penerbit Andi, Yogyakarta.

Begon, M., J. L. Harper., and C. R. Townsed. 1986. Ecology. Blacwell Scientific,Oxford.

Chasanah, L. R. 2010. Keanekaragaman dan Frekuensi Kunjungan Serangga Penyerbuk serta Efektivitasnya dalam Pembentukan Buah Hoya multiflora Blume (Asclepiadaceae). (Thesis). Insitut Pertanian Bogor,Bogor.

Corbet SA.,M. Fussell., R. Ake., A. Fraser., andC. Gunson. 1993. Temperature and pollination activity of social bees. Ecol Entomol 18:17-30.

Erwan. 2003. Pemanfaatan Nira Aren dan Nira Kelapa Serta Polen Aren Sebagai Pakan Lebah Untuk Meningkatkan Produksi Madu Apis cerana . [Tesis]. Program Pascasarjana. Institut Pertanian Bogor, Bogor.

Gojmerac, W. L. 1983. Bees, Beekeping, Honey and 
Pollination. AVI Publishing Company, Inc. Westport, Conecticut.

Guslim. 2007. Agroklimatologi.USU Press, Medan.

Hadisoesilo, S. 2001. Keanekaragaman Spesies Lebah Madu Asli Indonesia. Biodiversitas. 2 (1):123-128.

Hadisoesilo, S., G.W. Otis., and M.Meixner. 1995. Two distinct populations of cavity nesting honey bees (Hymenoptera, Apidae) in South Sulawesi, Indonesia. Apidologie 68: 399407.

Hilario SD, Imperatriz-fonseca V.L., klainert A. de MP. 2000. Flight activity and colony strength in the stingless bee melipona bicolor-bicolor (Apidae, melliponinae). Rev Brasil Biol 60:299-306.

Husaeni EA. 1986. Potensi Produksi Nektar dari Tegakan Kaliandra Bunga Merah (Calliandra calotyrsus Meissn.). Di dalam: Pembudidayaan Lebah Madu untuk Peningkatan Kesejahteraan Masyarakat. Prosiding Lokakarya; Sukabumi, 20-22 Mei 1986. Perum Perhutani. hlm: 87-91.

Keller, I., P. Fluri., and A. Imdorf. 2005. Pollen nutrition and colony development in honey bees-part II. Bee Word. 86: 2734.

Kevan P. G., R. W. K. Punchihewa., and C. F. Greco. 1995. Foraging range for Apis cerana and its implications for honey production and apiary management in Kevan PG (ed.), The Asiatic Hive Bee: Apiculture, Biology, and Role in Sustainable Development in Tropical and Subtropical Asia. Ontario, Canada: Enviroquest: 223-228.

Mattu, V. K., andL. R. Verma. 1984a. Comparative morphometric studies on the Indian honeybee of the North. West Himalayas. 2. Wing JApic Res 23(1):3-10.

Mattu, V. K., and L. R. Verma. 1984b. Comparative morphometric studies on the Indian honeybee of the North. West Himalayas. 3. Hind leg, tergites and sternit. J.zool 199: 1-29.

Michener, C.D. 1974. The Social Behaviour of The Bees. The Belknap of Harvard Univ Press, Cambridge.

Morse, R. A., and T. Hooper. 1985. The Illustrated Encyclopedia of Beekeeping. Blanford Press,England.

Murtidjo, B. A. 1991. Memelihara Lebah Madu.Penerbit Kanisius, Yogyakarta 
Roubik, D. W., and J. D. Ackerman. 1987. Long-term ecology of euglossine orchid-bees (Apidae: Euglossini) in Panama. Oecologia73:321-333.

Ruttner, F. 1988. Biogeography and Taxonomy of Honeybees.SpringerVerlag:Berlin

Saepudin, R., A. M. Fuah., dan L. Abdullah. 2011. Peningkatan Produksi Lebah Madu Melalui Penerapan Sistem Integrasi dengan Kebun Kopi. Universitas Bengkulu, Bengkulu, Indonesia..

Steel, R.G.D, dan J.H. Torrie. 1993. Prinsipdan Prosedur Statistika Suatu Pendekatan Biometrik. Terjemahan: M. Syah. PT. Gramedia Pustaka Utama, Jakarta.
Tilde, A.C., S. Fuchs., N. Koeniger., and C. R. Cervancia. 2000. Morphometric diversity of Apis cerana Fabr. within the Philippines, Apidologie 31: 249-264.

Tingek, S., M. Mardan., T. E. Rinderer., N. Koeniger., and and G.Koeniger. 1988. The rediscovery of Apis vetchi Maa 1953: The Sabah honeybee. Apidologie 19: 97-102

Wu, Y., and B. Kuang. 1987. Two species of small honeybee-a study of the genus Micrapis. Bee World 68: 153-155 